\title{
Corporate Sustaining Members, 1997-98
}

Alberta Environmental Protection

Avenor Inc.

Bowater Mersey Paper Co.

Canadair/Bombardier

Canadian Forest Service

Canadian Forestry Equipment Ltd.

Canadian Pulp and Paper Association

Canadian Woodlands Forum

Canfor Corporation

Chapleau Forest Products Ltd.

Corporation of the City of Sault Ste Marie

Crestbrook Forest Industries

Daishowa-Marubeni Int. Ltd.

Davis and Company

E.B. Eddy Forest Products Ltd.

Forest Alliance of British Columbia

Fraser Paper Inc.

Groupe de Recherche Ecologie Forestière

Hydro-Québec

Industrial Forestry Service Ltd.

J.D. Irving Ltd., Woodlands Division

La fôret modele du bas-Saint-Laurent Inc.

Lignum Limited

Logging and Sawmilling Journal

Newfoundland Department of Forest

Resources and Agrifoods

Ontario Ministry of Natural Resources
P.E.I. Department of Agriculture and Forestry

Pine Falls Paper Company

Repap New Brunswick Inc.

Riverside Forest Products Ltd.

School of Forestry, Lakehead University

St. Anne-Nackawic Pulp Co. Ltd.

Woodlands Division

Stone Container (Canada) Inc.

Stone-Consolidated Corporation

Stora Forest Industries Limited

Tembec Inc.

Tim J. White

Timberjack Inc.

Timberline

Tolko Industries Ltd.

Town of Hinton

Uniboard Canada Inc.

University of Toronto, Faculty of Earth Science Centre University of New Brunswick, Faculty of Forestry

Université de Moncton

University of British Columbia

University College of the Cariboo

Weldwood of Canada Limited

West Fraser Mills Ltd.

Weyerhaeuser Canada Ltd., BC Division

Weyerhaeuser Canada Ltd.

Wildfire Equipment Inc.

The Contribution of our Corporate Sustaining Members is Gratefully Acknowledged 